\title{
Negotiated Order in Political Budget
}

\author{
Kaspinor* \\ Postgraduate Program, University of Muhammadiyah Malang Indonesia
}

*Corresponding Author: Kaspinor, Postgraduate Program, University of Muhammadiyah Malang Indonesia

\begin{abstract}
The Local Government Budget (APBD) is the result of regional government policies that run from a series of long processes that involve discussions between the Executive and Legislative institutions. This opens up various chance and opportunities to negotiation for who have certain interests.

This study aims to understand, identified and described the political budgeting process and the interest form of the budget policy actors in Kubumaya Province. This research uses social definition paradigm, qualitative method with phenomenological research type and Negotiated Order as a grand theory. Methods of data collection through participant observation, in-depth interviews, documentation.

The results showed that there was a Negotiated Order process in political budgeting of Kubumaya Province in the form of a 'Rapat Setengah Kamar'. This meeting is usually held between the Executive and Legislative institutions related to the discussion of budget politics, which occurs continuously, creating a social order. Rapat Setengah Kamar, which is an informal meeting, has a big influence on the final result of the APBD.
\end{abstract}

Keywords: APBD, Negotiated Order, Executive, Legislative

\section{INTRODUCTION}

Since Law no. 23 Year 2014 concerning Local Government was enacted, the Central Government initiated to emphasize the principle of Local Autonomy, in which each Local Government has authority to regulate their own local finances. The law also explains that the autonomy provides extensive opportunity for the regions, so that the government is able to increase the public's welfare, to improve public services and to increase local competitiveness. This freedom is then manifested into the formulation of a Local Government Budget (APBD) which involves the Executive and Legislative members of each region. The ideal goal that must be achieved is to actualize the local independence by utilizing local potential or wealth as much as possible for the public's welfare.

In accordance with Government Regulation no. 12 Year 2019 concerning Guidelines for Local Financial Management, APBD is an annual local financial plan that comprises Local Revenue, Expenditure and Financing. However, APBD is not only a local financial plan, but also a Local Government development planning document that reflects the track of Local Government development policies that must be allocated for public's welfare and be distributed appropriately and fairly.

Due to having long process and involving many parties, it opens up various opportunities for negotiations by parties who have certain interests. Several formal meetings that had been planned from previous year or Bottom-Up, such as Community Consultations on Development Planning (Musrembang) of Sub-district, District/City, Province, and up to National, that prioritizes activity program and seeks for funding sources. The meeting of the Local Government of Budget Committee (TAPD) and Budget Committee (Banggar) of DPRD (Regional Representative Assembly) has become the room to do lobbying of various negotiations that are largely on behalf of the public's interest. But in reality, there are also various informal meetings such as Closed Meetings that involve stakeholders with the aim of discussing and negotiating the budget amount and concreter commitments according to the expectations of each party. So that it can be used to realize interests on behalf of the publics (aspiration network), party interests, maintaining relationships and building communication.

The process of budget drafting is, apparently, not inclusive. Even though the mechanism of the drafting process goes through very long and difficult journey, that almost all members are inseparable 
from the planning process, allowing agreements stages occur at between the Legislative and the Executive until a joint decision is made. The impact, public interest becomes marginalized, such as the elderly, the women and children, and the poor are, in general, the most powerless. The public are socially, economically, and politically become weak (Wahab, 2002).

Negotiations on behalf of interests of individuals, parties or certain groups are common in around the Executive and Legislative in the Local. Negotiations are carried out by someone or a party due to an 'order' of the parties that have Power (Strength) and Legitimacy (Authority). In the book of Fundamentals of Political Science written by Prof. Miriam Budiarjo explained that the source of power can come from one's position, amount of wealth and the public's trust to that figure.

So many informal meetings that are not a part of the APBD planning and approval process are held, that in fact, are able to influence the final outcome of the APBD. This phenomenon is unique and very interesting to study and understand further. Since, all APBD planning can only be designed by the Local Executive and Legislative, and the budget in the APBD should really be used for the benefit of the publics. However, the reality is not all and, on the contrary, shows that the APBD has not fully stood on wider public's interests and needs, and the process passed is merely to meet normative standards that it is in accordance with Law Regulations.

\section{LITERATURE REVIEW}

\section{A. Negotiated Order}

The Negotiated Order Theory was developed by Anselm Strauss and his colleagues in 1960s and 1970s (Strauss, 1978). It is an outgrowth of social interactionist theory, unlike previous functionalist theory which emphasized social change and dynamic nature of social order (Dayand Day, 1977). The main assumption of the Negotiated Order theory is that '...organizations unite not because of the structure of their roles, yet because the members consciously or unconsciously construct and reconstruct orders, constantly negotiate formal and informal arrangements among themselves' (Baïada-Hirèche et al, 2011: 19).

Strauss (1987) summarized the original formulation of the Negotiated Order into the following statements; a) Social order is a Negotiated Order, there is no organizational relationship without negotiations that accompany; b) Specific negotiations appear to depend on specific structural conditions: who negotiates with who, when, and about what. So, the negotiations are patterned and not accidental; c) The results of a negotiation are in the form of contract, understanding, promise, rules, and so on that all have temporal boundaries, and that eventually all these results will be reviewed, re-evaluated, revised, repealed or updated; d) Negotiated Order must be carried out based on collective action, need to be continually rearranged and new negotiations are made every day; e) Negotiated Order on particular day can be considered as the total number of the organization's rules and policies, along with any agreements, understandings, facts, contracts, and any work arrangements obtained recently. It involves agreements at every level of organizations, groups and coalitions, including covert and open agreements; f) Any changes that occur in Negotiated Order, whether ordinary or unordinary, are called negotiations or re-evaluation. This means a change as a result of the Negotiated Order; g) the day-to-day negotiation process gives reactions/impacts on organizations, rules, policies that are more formal and permanent.

In the Negotiated Order theory, social order is negotiated and re-negotiated through a recursive relationship between structural context, negotiation context, social interaction and the result (Dokko et al., 2012: 686). Negotiated Order is a consequence of the interaction of take-and-give in a setting that is predetermined by the rules, norms, laws, or wider expectations, and usually more formally, in order to secure the desired goal (or "bets").

Strauss argued that social order is a Negotiated Order. Negotiation, according to Strauss, is "one of the possible ways to achieve something when parties need to deal with each other to solve things" (p.234). In order to approach social phenomena from the perspective of the Negotiated Order Theory, both structural context and negotiation context must be explored. According to Strauss (1978), the specific nature of the negotiating context is (p. 238); a) The number of negotiators, their relative experience in negotiating, and who they represent; b) Whether the negotiation is one-time, repeated, sequential, serial, multiple, or linked; c) The relative balance of power shown by each party in the negotiation itself; d) The nature of the respective stakes in negotiations; e) Visibility of transactions to 
others; that is, their character is overt or covert; f) The number and complexity of issues negotiated; g) Clarity of the limits of the legitimacy of the negotiated issue; and h) Options to avoid or stop negotiations; that is, alternative modes of action that are considered available.

\section{B. Political Budget}

Wildavsky and Caiden (2004) explained that budgeting is a process in which various kinds of individuals or groups who have interests convey different desires and decisions. To get decisions from various interests, they convey arguments about things that are considered right and fair. Whereas in the 'body' of the Executive itself, conflicts occur in the choice of policies in budgeting. Given the limited amount, the funds available in the budget must be divided proportionally, thus requiring a mechanism for sharing and prioritizing expenditure options.

A budget is multi-dimensional, Hyde (1992) stated his views on budget as follows; As a political document, a budget is created to allocate scarce resources to publics among complex, competitive and even conflictual interests; As an economic and fiscal document, the budget is the main tool for evaluating the income distribution process, increasing economic growth, reducing inflation, promoting employment and maintaining economic stability; As an accounting document, the budget is a guideline and ceiling for government spending; As a managerial and administrative document, the budget is an instrument that helps direct the provision of services to the public.

Wildavsky and Caiden (2004) said, Political budget will be associated with anyone who plays a role and the state's ability to guarantee its people. But to what happened, Political Budget is understood and practiced only in the short-term context and profitable that only benefit for certain parties.Rulesin determining the implementation of the program only on the level of interest of the actors involved, while the public is not at all involved in the process that occurs, this results public ignorance regarding the budget's amount or percentage to be used for their welfare.

Wildavsy and Kaiden (2012) suggested several definitions of Political Budget, they were; a) Political budget is the determination of various policies regarding budgeting process which includes how government finances its activities; how money is obtained, managed and distributed; who benefits and loses; what opportunities are possibly available to do deviations or improve public services; $b$ ) the process of mutual influence among various parties with interests in determining development priorities with limited funding sources; c) the process of influencing the budget allocation policies carried out by various parties with an interest in the budget; $d$ ) the process of affirming political power among various parties involved in determining policies and budget allocations.

\section{METHOD}

This study used a social definition paradigm and through a phenomenological qualitative approach in Kubumaya Province as the location, Madya Raya City (a pseudonym). The research subjects were selected from the Executive element, namely TAPD (Local Government of Budget Committee) and the Legislative element, namely Banggar DPRD (Budget Committee of Regional Representative Assembly) Kubumaya Provincial Government. Subjects were selected purposively with the following criteria: (1) The research subjects had long and intensively integrated into the activities and fields that became the research study, (2) The research subjects were fully involved in the activity or field, (3) The research subjects had sufficient time to be asked for information (Creswell, 2010). Based on those criteria, five people were selected as research subjects.

The data observation in the qualitative study focused on the researcher's observation himself, the researcher described how the policy-making of budgeting process in Kubumaya province by following the process from the initial drafting, discussion, establishment and implementation of the APBD. Afterwards, data collection was also carried out through in-depth interviews and documentary analysis. The in-depth interviews to all who have been as the subject is to investigate deeply regarding verbal data as well as to seek in-depth meaning of the findings that were observed. The whole data were then analyzed in accordance with the phenomenological model of analysis.

\section{RESULTS AND DISCUSSION}

The analysis of this study was divided into two parts, the first described how the budget policy making process was carried out consciously by budget policy makers in real conditions. The second was to find out what factors that created the Negotiated Order in political budget in Kubumaya Province. 


\section{Budget Policy Making Process in Kubumaya Province}

The budget policy making process in Kubumaya Province consists of; 1) Budget Policy Planning;2) Discussion, Determination and Implementation of Policies. This is in accordance with Government Regulation (PP) No.12 Year 2019 concerning Local Financial Management. For the preparation stage starting from the VISION and MISSION and the programs of the elected Local Headwill be interpreted into development priorities and main strategies, targets and policy directions, as well as various main programs and activities that will be implemented by the Local Government Work Unit (SKPD). All the ideas of the Local Head are contained into Local go government medium term development plans (RPJMD) which becomes the benchmark for the local head's performance. The process of preparing the initial draft of the development plan is carried out by SKPD that functions as an extension of the government, namely Bappeda (Local Development Planning Agency). Bappeda then compiles the RKPD (Local Government Plan) which becomes the reference and the RPJMD (Local go government medium term development plans) becomes the basis. The determination of this RKPD goes through a long process through the Musrenbang (Community Consultations on Development Planning) from the village up to the province level until the final RKPD (Local Government Plan) is enacted. In the planning process, several tendencies and field data found indicated that 1) Based on the RKPD generated through the Musrenbang forums, it seems that it has not been optimally accommodated; 2) The preparation of the RKPD document is a formality and is not yet fully used as a reference by actors in prioritizing the preparation of the next budget document. The draft RKPD document is then prepared by Bappeda itself through the Copy-Paste mechanism. This is as stated by a member of the TAPD (Local Government of Budget Committee) of Kubumaya Province as follows;

"The RKPD is indeed prepared by Bappedalitbang (Local Development Planning and Research Agency) based on the results of the musrenbang, although the material or aspirations of the public are not widely accommodated due to adjusting the limited budget. Like Musrenbang, the preparation of RKPD documents also tends to do copy-paste, SKPD also tends to provide SKPD strategic work plandrafts to repeat the program from the previous year. The discussion on determining priorities will run formally and smoothly, which will be tough when discussing with the DPRD about the amount of the budget in a program."

3) There is an inconsistency between policy direction and planning. To explore the phenomenon of inconsistency between the direction of development and local planning, it can be seen in the comparison table of planning documents and budget documents of Kubumaya province for 2017-2019 budget years, as follow:

\begin{tabular}{|c|c|c|c|c|c|c|c|}
\hline \multirow{2}{*}{$\begin{array}{l}\text { Plan } \\
\text { Type }\end{array}$} & \multirow{2}{*}{ Year } & \multicolumn{6}{|c|}{ Budget Group } \\
\hline & & Direct Budget & $\%$ & Indirect Budget & $\%$ & Total & $\%$ \\
\hline \multirow{3}{*}{ RPJMD } & 2017 & 1.563 .191 .036 .000 & 39 & 2.422 .976 .341 .726 & 61 & 3.986 .167 .377 .726 & 100 \\
\hline & 2018 & 1.730 .344 .150 .934 & 42 & 2.358 .055 .516 .291 & 58 & 4.088 .399 .677 .225 & 100 \\
\hline & 2019 & 1.805 .063 .068 .323 & 43 & 2.399 .838 .337 .608 & 57 & 4.204 .901 .405 .931 & 100 \\
\hline \multirow{3}{*}{ RKPD } & 2017 & 1.493 .133 .098 .000 & 44 & 1.926 .592 .038 .000 & 56 & 3.419 .725 .136 .000 & 100 \\
\hline & 2018 & 2.162 .345 .062 .274 & 47 & 2.457 .410 .146 .526 & 53 & 4.619 .755 .208 .800 & 100 \\
\hline & 2019 & 2.532 .421 .921 .789 & 50 & 2.503 .275 .086 .358 & 50 & 5.035 .697 .008 .147 & 100 \\
\hline
\end{tabular}

Table4.1. The comparison of Current Kubumaya Provincial Planning Documents for 2017-2019

Source: Processed from RPJMD and RKPD Kubumaya Province 2019 running

From table 4.1. It can be seen that a significant change in RKPD against the reference of the RPJMD document, from the 2017 RKPD data up to the 2018 budget year, it can be seen that the budget volume has increased drastically from the figure in 2017 that was 3.419 trillion yet in 2018 was 4.619 trillion, an increase up to 1.200 trillion. In contrast to the RPJMD planning, in 2017 the planned budget was 3.986 Trillion and in 2018 it was only 4.088 Trillion, so an increase of approximately 101 Billion. This shows that there has been a budget inconsistency in the RKPD, which was originally stated and agreed upon in the RPJMD.

Furthermore, in the process of Discussion, Determination and Implementation of Policies in Kubumaya Province. After the results of Musrenbang at Provincial level in the form of RKPD 
document, which becomes the elaboration of the results of the joint decision in SKPD forum wasKUA-PPAS (General budget Policies - Provisional budget priorities and funding level). The KUA-PPAS results from the determination of the RKPD will be discussed further together with the legislative, namely through the forum of DRPD Budget committee (Banggar) Kubumaya Province. However, before entering to the discussion forum, TAPD also conducted budget discussions, namely the RKA (Local Government work plan and Budget) of each SKPD that had been listed in the RKPD. Based on the research results, it is known that there is a relevance between what the researcher found in the field and the Negotiated Order theory which is the basis of the research. This also clarifies the suspicion that this phenomenon occurs in almost all parts of the world, including in Indonesia. An informal arrangement other than formal (TAPD Meeting, Banggar Meeting, Gabungan Meeting) that are formed and survives under the supervision of actors that is in fact capable of influencing the final outcome or budget decisions at formal meetings. In brief, the process of the Negotiated Order Practices in Kubumaya Province can be described in the following chart;

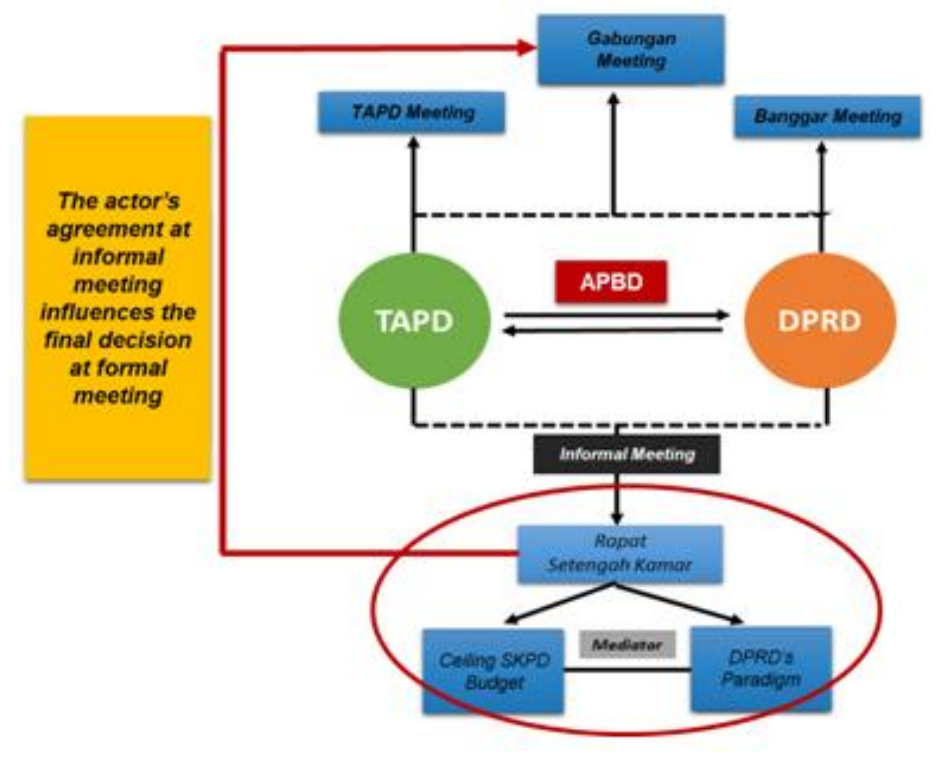

Chart4.1. Negotiated Order Practice on political budget in Kubumaya Province

TAPD as an extension of the Executive Party has an equal position with the DRPD Budget committee (Banggar) as an extension of the DPRD or the Legislative Party. Based on Law no. 23 of 2014, both of them are part of the Local Government that must go through various processes including; Planning, discussion and determination to reach APBD agreement. In the political budget process in Kubumaya Province, TAPD holds a TAPD Meeting to discuss the budget requirements required by each SKPD that has to be accommodated. Meanwhile, the DPRD Banggar holds a Banggar Meeting to discuss the basic needs of paradigm (Pokir) that has to be accommodated to fulfill the public's aspirations.

In terms of reaching a mutual agreement, a formal meeting is held in the form of a Gabungan Meeting which is based on the researcher's observations, it never immediately creates an agreement and tends to be deliberately escorted by the actors to create a suspension or deadlock so that the decision can be postponed. During that time, the actors hold a 'Rapat Setengah Kamar', which is a limited informal meeting attended by representatives of both the TAPD and the DPRD Banggar. It is said to be informal because the existence of this meeting is not mentioned in the Law regulations. The term of 'Rapat Setengah Kamar' is indeed foreign for publics, but not for actors making budget policies, as observed by researcher in formal meetings (Banggar Meeting);

"Okay, let me asked the Local Secretary first. How is it? As suggested by the Banggar team, Sir? ${ }^{1}$

If we need break, we take a break, we will give input first ${ }^{2}$

No, this is not. I suggested that we try to have 'Rapat Setengah Kamar', so it would be moretransparent later

\footnotetext{
${ }^{1}$ DPRD's voice - B (Observation result on Banggar Meeting on 12 November 2018)

${ }^{2}$ DPRD's voice - F (Observation result on Banggar Meeting on 12 November 2018)
} 
This meeting is purely an order that is deliberately formed and maintained continuously by the actors, as to create the practice of the Negotiated Order. At this meeting, they negotiate solutions and decisions to problems discussed in previous formal meetings.

In the end, the decisions that both parties agreed upon at the 'Rapat Setengah Kamar'were 'bagged' and taken to the formal meeting,to be then agreed formally and based on Law regulations. This is what makes researcher concludes that decisions that have been made at informal meetings are in fact ableto influence decisions made at formal meetings. Although this research focuses on the Negotiated Order process in political budget in Kubumaya Province, this dissertation will also explain various facts found by researcher during the research period.

\section{1) The DRPD's Paradigm (Pokir DPRD)}

Legal standing on paradigm (pokir) does exist. By then, each member of the council continues to fight so that the programs/activities can be allocated. It is not surprising that each meeting will run very tough and dynamic until the agreement is reached from both parties (TAPD \& Banggar DPRD). At another occasion, the researcher conducted an interview with one of the TAPD members in the hope of obtaining a little picture of the Executive's view of the existence of a pokir. The data obtained from the interview showed that the practice of Negotiated Order related to Pokir also occurs between the Legislative and the Executive, which is in the form of request for the grant funds distribution of for electoral districts where DPRD members are elected that are believed to realize the pokir. The following statement was evident;

"So, there are several members of the council communicating with me. Like, Mr. FE, he often asks regarding the distribution of grant funds in his electoral district.There are also Mr. J and Mr. H, although I do not know the arrangement for the grant funds distribution, then I just said, 'OK, I'll ask the technical sector'there are a lot, right? so I often forget",

\section{2) Negotiation of the Ceiling for Local Government Work Units (SKPD)}

The practice of Negotiated Order that occurs in ceiling budget negotiations can be seen from the distribution of Pokir's council which is not only discussed in formal forums. The potential for legitimacy from the DPRD will tend to be more dominant in creating narratives for conducting budget negotiations. By the programs/activities accommodation that have been approved by the TAPD, the amount of the budget determined is the result of interest exchange. If referring to the informant's statement, the interest exchange is in the form of increasing the budget volume in the provision of cattle assistance, which there are initially only three, but with the efforts made by DPRD actors, desiring to change the volume of assistance on behalf of the public's interest. This change in the volume of assistance certainly affects the SKPD ceiling indicative which, of course, can accommodate the DPRD's needs. This is a mutually beneficial exchange both from proposing an increase of highest limit budget (DPRD) or the proposed party (SKPD). This is reinforced by informant's statementas the interview results by the researcher with Mr. L (TAPD from Bappeda Kubumaya Province);

"Ya, but it is usually directed anyway, it is held, for example, a livestock assistance program, indeed, our money is limited. The suggestion from the district is 5, then, out of 5, the money is limited only 3. As we know the discussion with the council is kind of question and answer, then sometimes the SKPD is lured. Ohh, the SKPD seems to have lack of budget for the assistance of cattle, then let's just add some more ${ }^{\prime 5^{5}}$

Well, the negotiations took place there, right? ${ }^{6}$

It could also happen there, the council has regional interests, right? On the other hand, the SKPD has interests to the programtoo ${ }^{7}$

\section{3) Budget Political Mediator}

Apart from the phenomenon of 'Rapat Setengah Kamar', pokir, and negotiation of the indicative ceiling, there is also the phenomenon of mediators. The function of the mediator here is to act as a mediative regulator. The mediator is described as one who is able to identify and formulate the

\footnotetext{
${ }^{3}$ TAPD's voice - A (Observation result on Banggar Meeting on 12 November 2018)

${ }^{4}$ TAPD's informant -1 (Interview result with Mr. A on 3 November 2018)

${ }^{5}$ TAPD's informant -2 (Interview result with Mr. L on 5 October 2020)

${ }^{6}$ Researcher (Interview result with Mrs. L on 5 October 2020)

${ }^{7}$ TAPD's informant - 2 (Interview result with Mrs. L on 5 October 2020)
} 
negotiation substance. Using communication techniques in order to translate statements, explain needs, encourage understanding, gather information and assist the process of exchanging information between the parties and most importantly be able to prepare a negotiation agenda. The mediator is described as a person who is very skilled and experienced in budgeting problems. Mediators tend to use interest-based negotiation, which is based on this approach, the all-parties'interests can be represented. The objective of the mediation process and interest-based negotiation is an agreement that satisfies the needs and interests of all parties concerned through the process of identifying interests and formulating options and alternatives in accordance with those interests. As an example of the mediator's role described above, the followings are the results of the researcher's interview with Mrs. E, a former member of DPRD Kubumaya Province;

It just depends on the lobbying with the chairman, the reason why I can lobby the chairman because I am close to DPRD chairman, it just depends on the lobby of how many budgets being asked for. ${ }^{8}$

But now it's vulnerable, unlike what I used to be. ${ }^{9}$

Yes, don't get caught, it has to be someone who is not clear there, like me who is no more at the council, that's why I'm not taking part in politics for a while, right, so I'm the one who sometimes becomes the mediator. If they want to enter there, and not with the same person (the mediator), they reject. For example, we need budget for things, then go taking up... ${ }^{10}$

\section{CONCLUSiON}

The budget policy making process includes several stages, which can be briefly described as follows; 1) Planning begins by making a Local go government medium term development plans (RPJPD) by considering the National go government medium term development plans (RPJMN); 2) After the RPJMD is stipulated, the Government then prepares a Local Government Plan (RKPD); 3) Then based on the existing RKPD, the Local Head prepares an APBD draft of General budgetary Policies (KUA); 4) The draft is then discussed with DPRD to determine priority activities and the Interim budget priorities and funding ceilings used (PPAS); 5) Then the Local Head issues the Preparation Guidelines of Local Government work plan and Budget (RKA) SKPD as a guide for the SKPD Head in compiling RKA-SKPD based on the Memorandum of Understanding; 6) After the RKA-SKPD is drawn up, the Local Government prepares a Local regulation plan concerning the APBD and a draft regulation concerning the elaboration of the APBD; 7) Finally, the regulation is evaluated and then stipulated as APBD.

Based on the results of field observations and in-depth interviews with research subjects, it was found that, in the budget policy-making process, there was a Negotiated Order practice in the form of a 'Rapat Setengah Kamar'which was a closed meeting among members of TAPD as an extension of the BanggarDPRD as an extension of the Legislative party. A 'Rapat Setengah Kamar'is a meeting that is deliberately escorted by the actors to become a forum for decision making based on each party's interests. In this case, the Executive'sinterests are to accommodate all the needs of Local Government Work Unit (SKPD) while the Legislative's interests are to accommodate all of the DPRD's paradigm (Pokir) which are the publics' aspirations. 'Rapat Setengah Kamar'is an informal meeting whose existence is not regulated in a Law regulation, however budget decisions in this meeting are finalized and then taken to formal meetings.

The results also found that, in the budget policy making process, there are 'Mediators' who play a role in bridging or mediating the policy-making actors. Mediators may come from both the Executive or the Legislative Circles. Mediators are usually experienced in conducting negotiation processes and have close relationships with policy-making actors. In the end, the activities of the 'Rapat Setengah Kamar'are carried out continuously, escorted and defended by the actors to make a beneficial decision to both parties, becoming a social order in the form of Negotiated Order practices in political budget.

\section{BIBLIOGRAPHY}

[1] Bogdan, Robert dan Steven Taylor. 1992. Pengantar Metode Kualitatif. Surabaya: Usaha Nasional.

\footnotetext{
${ }^{8}$ DPRD's subject - 2 (Interview result with Mrs. L on 13 December 2019)

${ }^{9}$ Researcher (Interview result with Mrs. L on 13 December 2019)

${ }^{10}$ DPRD's subject - 2 (Interview result with Mrs. L on 13 December 2019)
} 
[2] Creswell, J. W. (2010). Research design: pendekatan kualitatif, kuantitatif, dan mixed. Yogjakarta: PT Pustaka Pelajar.

[3] Dye, Thomas R. 1992. Understanding Public Policy. USA. Prentice-Hall.

[4] Denzin, K. Norman., Lincoln, S. Yvonna. (2011). The sage handbook ofqualitative research, Yogyakarta : Pustaka Pelajar

[5] George Ritzer, 1992, Sosiologi Ilmu Pengetahuan Berparadigma Ganda,. Penyadur: Alimandan, Rajawali Press, Jakarta.

[6] Guba, Egon. G.; Lincoln, Yvonna. S. (1988) Do inquiry paradigms implyinquiry methodologies?, In D. M. FETTERMAN (Ed) QualitativeApproaches to Evaluation In Education: The Silent ScientificRevolution. New York: Praeger, pp.89-115.

[7] Ritzer, George. 2014. Sosiologi Ilmu Pengetahuan Berparadigma Ganda. Jakarta Raja Grafindo Persada.

[8] Roger Fisher; William L. Ury; Editor-Bruce Patton. 1993.Getting to Yes:Negotiating Agreement Without Giving In 2nd (second) edition

[9] Wildavsky. Aarone Naomi Caider, 2004. The New Politic of The Budgetary Process Fifth Edition Published by Pearson Education Inc

[10] Wildavsky, Aaron, Naomi Caiden. 2012. Dinamika Proses Politik Anggaran. Yogyakarta: Matapena Consultindo

[11] Day, R. \& Day, J.V. (1977). A Review of the Current State of Negotiated OrderTheory: An Appreciation and a Critique. The Sociological Quarterly, 18, 126-142

[12] Strauss, Anselm. (1978). Negosiations: Varietes, Contexts, Processes, and Social Order, San Fransisco : Jossey-Bass.

(1970). Discovering New Theory from Previous Theory. In T. Shibutani (Ed.).

(1970). Human Nature and Collective Behaviour. Englewood Cliffs. N.Y. : Prentice - Hall. and others. (1964). Psychiatric Ideologies and Institution. New York : Free Press. (1959). Mirrors and Masks : The Search for Identity. Glencoe, Illnoiss, Free Press.

[13] Undang-Undang Republik Indonesia Nomor 25 Tahun 2004 Tentang Sistem Perencanaan Pembangunan Nasional

[14] Undang-Undang Republik Indonesia Nomor 10 Tahun 2004 Tentang Pembentukan Peraturan PerundangUndangan

[15] Undang-Undang Republik Indonesia Nomor 23 tahun 2014 Tentang Pemerintahan Daerah

[16] Peraturan Kementrian Dalam Negeri Nomor 86 Tahun 2017 Tentang Tata Cara Perencanaan, Pengendalian dan Evaluasi Pembangunan Daerah, Tata Cara Evaluasi Rancangan Peraturan Daerah Tentang Rencana Pembangunan Jangka Panjang Daerah dan Rencana Pembangunan Jangka Menengah Daerah, Serta Tata Cara Perubahan Rencana Pembangunan

[17] Peraturan Kementrian Dalam Negeri Nomor 38 Tahun 2018Tentang Pedoman Penyusunan Anggaran Pendapatan Dan Belanja Daerah Tahun Anggaran 2019

[18] Peraturan Pemerintah Nomor 12 Tahun 2018Tentang Pedoman Penyusunan Tata Tertib Dewan Perwakilan Rakyat Daerah Provinsi, Kabupaten, dan Kota

[19] Peraturan Pemerintah Nomor 12 Tahun 2019 Tentang Pengelolaan Keuangan Daerah

Citation: Kaspinor. "Negotiated Order in Political Budget" International Journal of Humanities Social Sciences and Education (IJHSSE), vol 8, no. 4, 2021, pp. 34-41. doi: https://doi.org/10.20431/23490381.0804005.

Copyright: (c) 2021 Authors. This is an open-access article distributed under the terms of the Creative Commons Attribution License, which permits unrestricted use, distribution, and reproduction in any medium, provided the original author and source are credited. 